"Przegląd Prawa Konstytucyjnego"

----- ISSN 2082-1212 ------

DOI 10.15804/ppk.2014.04.09

Nr $4(20) / 2014$

\title{
Sprawozdanie
}

\section{Zjazd Katedr i Zakładów Systemów Politycznych, Ostromecko, 3-4 kwietnia 2014 r.}

Trzeci Zjazd Katedr i Systemów Politycznych został zorganizowany przez Wydział Politologii i Studiów Międzynarodowych Uniwersytetu Mikołaja Kopernika w Toruniu i miał charakter dwudniowy. Przygotowania związane $\mathrm{z}$ jego organizacją zostały przeprowadzone przez komitet organizacyjny, w którym znaleźli się: dr hab. Danuta Plecka oraz dr hab. Joanna Marszałek-Kawa jako kierownicy naukowi oraz mgr Zuzanna Osmólska i mgr Katarzyna Miętkiewicz pełniące funkcje sekretarzy.

$\mathrm{Na}$ zaproszenie ze strony organizatorów odpowiedzieli przedstawiciele trzynastu uczelni z całej Polski. Reprezentowali oni te ośrodki, które w ramach wydziałów politologii i stosunków międzynarodowych prowadzą badania związane z problematyką systemów politycznych (rozumianych zarówno w ujęciu metodologicznym, jak i etatystycznym). Na liście uczestników znaleźli się politolodzy z: Uniwersytetu Warmińsko-Mazurskiego w Olsztynie, Uniwersytetu Mikołaja Kopernika w Toruniu, Uniwersytetu Śląskiego w Katowicach, Uniwersytetu Rzeszowskiego, Uniwersytetu Marii Curie-Skłodowskiej w Lublinie, Uniwersytetu Gdańskiego, Uniwersytetu Zielonogórskiego, Uniwersytetu Kazimierza Wielkiego w Bydgoszczy, Uniwersytetu Pedagogicznego w Krakowie, Uniwersytetu Wrocławskiego, Uniwersytetu Łódzkiego, Uniwersytetu im. Adama Mickiewicza w Poznaniu, Uniwersytetu Warszawskiego oraz Uniwersytetu Kardynała Stefana Wyszyńskiego w Warszawie.

Pierwszy dzień Zjazdu rozpoczęła dr hab. Danuta Plecka, która po powitaniu zebranych uczestników oddała głos profesorowi Romanowi Bäckerowi, 
dziekanowi Wydziału Politologii i Studiów Międzynarodowych UMK w Toruniu. Profesor w swoim wystąpieniu przedstawił ideę Zjazdu, odnosząc ją do szerszego kontekstu, jakim jest konieczność „otwarcia się polskiej politologii na zewnątrz”. Wskazał w tym zakresie na przykłady działalności International Political Science Association (IPSA), jak również na organizację I Kongresu Azjatyckiego, który odbędzie się w Toruniu w maju 2014 dzięki współpracy różnych podmiotów - w tym akademickich. W dalszej kolejności głos zabrał dr Adam Marszałek (Wydawnictwo Adam Marszałek), który kontynuując wątek prof. Bäckera, zauważył, że planowany Kongres Azjatycki poprzedziło siedem konferencji azjatyckich oraz współpraca $\mathrm{z}$ ambasadorami wielu państw.

W części merytorycznej III Zjazdu referat zatytułowany Nauka o systemach politycznych jako przyczynek do nauki o człowieku wygłosił prof. Andrzej Antoszewski z Uniwersytetu Wrocławskiego. W trakcie przemówienia profesor przedstawił ogólne refleksje na temat prawniczego (normatywnego) oraz politologicznego podejścia do badania systemów politycznych. Sprecyzował różnice o charakterze metodologicznym, odnosząc je do przykładów z zakresu najnowszych wydarzeń w stosunkach międzynarodowych - aneksji Krymu przez Federację Rosyjską. Profesor Antoszewski argumentował, że analiza aktów normatywnych w wielu przypadkach ma charakter niewystarczający z punktu widzenia wyjaśniania zmian zachodzących w ramach systemów politycznych. Badania prowadzone przez konstytucjonalistów nie są w stanie odpowiedzieć na pytanie o granicę pomiędzy przepisami prawa i rzeczywistością polityczną. Samo analizowanie norm konstytucyjnych (np. konstytucji Turkmenistanu) nie doprowadzi do uzyskania odpowiedzi na pytanie o rzeczywisty charakter istniejącego systemu politycznego. Dopóki nie skonfrontujemy konstytucji z rzeczywistością, przy zastosowaniu metod typowych dla politologii, dopóty nie jesteśmy w stanie odpowiedzieć na pytanie dlaczego rzeczywistość odbiega od norm.

W odniesieniu do bieżących wydarzeń międzynarodowych profesor analizował kwestię aneksji Krymu - która niezależnie od oceny zgodności z normami prawa międzynarodowego (część prawników argumentuje, że była z nimi zgodna, a część, że nielegalna) jest zaborem (aneksją) części terytorium Ukrainy. Zadaniem nauki o systemach politycznych nie jest odpowiedź na pytanie o legalność tych działań, tylko o to, dlaczego politycy się na to 
zgodzili? Funkcją nauki jest poszukiwanie odpowiedzi na pytanie: w jakich warunkach model normatywny jest realizowany w praktyce, a w jakich warunkach nie jest?

Profesor wyjaśnił, że naukę o człowieku rozumie w sensie dynamicznym, jako naukę o działaniach ludzkich. System polityczny jest konstrukcją tworzoną, modyfikowaną przez człowieka, w tym sensie nauka o systemach politycznych jest „przyczynkiem do nauki o człowieku”. W dalszej kolejności poruszył problem podmiotowości politycznej, zauważając, że klasyczne podejście instytucjonalne pod względem zdolności eksplanacyjnej jest dzisiaj nieadekwatne, to samo dotyczy neoinstytucjonalizmu. W kontekście badań z zakresu funkcjonowania systemów politycznych istotne jest poszukiwanie odpowiedzi na pytanie: dlaczego w niektórych systemach politycznych ludzie się buntują przeciwko władzy, a w innych takie wystąpienia (pomimo autorytarnego systemu politycznego) nie mają miejsca? Wskazał w tym zakresie na odmienności występujące pomiędzy rosyjskim i ukraińskim systemem politycznym oraz tzw. kolorowe rewolucje.

Po wygłoszeniu wykładu dr hab. Michał Strzelecki rozpoczął dyskusję. W jej trakcie uczestnicy zadawali profesorowi pytania oraz wygłaszali refleksje związane z problematyką wystąpienia. Dyskusja pierwotnie zaplanowana na 90 minut, wydłużyła się do dwóch godzin. Wieczór pierwszego dnia III Zjazdu zakończyła uroczysta kolacja.

W drugim dniu uczestników powitała dr hab. Danuta Plecka, przedstawiając kolejnego z zaproszonych do wygłoszenia wykładu - profesora Tadeusza Godlewskiego z Uniwersytetu Mikołaja Kopernika w Toruniu. Wystąpienie zostało zatytułowane Rządzący i rządzeni - obywatelskie kompetencje polityczne jako kryterium demokracji. Profesor skoncentrował się na problemie badania kompetencji politycznych obywateli, wskazując na różnice pomiędzy badaniem kompetencji i preferencji wyborczych. Argumentował, że socjologiczne metody polegające na badaniu zagregowanych opinii nie są adekwatne w przypadku analizowania kompetencji obywatelskich, ponieważ w tym drugim przypadku jednym z problemów jest stopień poinformowania obywateli o polityce. Profesor zwrócił uwagę na fakt, że w tego typu analizach bardziej adekwatne są metody fokusowe niż ankietowe.

Część wystąpienia została poświęcona na przedstawienie problemu podziału kompetencji politycznych pomiędzy rządzonych i rządzących. Podział 
ten ulega ograniczeniu ze strony rządzących, ponieważ „władza nie chce być kontrolowana stale i po wyborach zazwyczaj zmierza w kierunku ograniczenia uprawnień obywateli w tym zakresie". W związku z tym badanie kompetencji obywatelskich nie powinno być ograniczone do analiz obywatela i jego zachowań wyborczych, ale poszerzone o badania jego opinii na różne kwestie związane z polityką - jako obywatela funkcjonującego w społeczeństwie cały czas. Profesor stwierdził, że w pewnym zakresie badania prowadzone odnośnie do kompetencji obywatelskich w skali mikro (lokalnej) mogą być odnoszone do skali makro, w celu ustalania kompetencji obywateli w sprawach ogólnopaństwowych, związanych ze sferą publiczną.

Wystąpienie zostało podsumowane w formie dyskusji, moderowanej przez prof. Katarzynę Sobolewską-Myślik z Uniwersytetu Pedagogicznego w Krakowie. Debata dotyczyła możliwości zastosowania mechanizmów demokracji deliberatywnej w celu poszerzania kompetencji obywatelskich. Pytania kierowane do prof. Godlewskiego dotyczyły budżetów partycypacyjnych i zasadności ich stosowania, problemu kształtowania kompetencji obywatelskich w skali makro, w odniesieniu do kwestii takich jak rozumienie zasad tworzenia budżetu, systemu podatkowego.

Po zakończonej dyskusji głos zabrał dr hab. Waldemar Wojtasik z Uniwersytetu Śląskiego w Katowicach, który zaprosił uczestników na zaplanowany na IV Zjazd Katedr i Zakładów Systemów Politycznych, który odbędzie się w Wiśle w maju 2015 r. Zjazd podsumowała oraz zakończyła dr hab. Danuta Plecka, dziękując gościom za uczestnictwo.

Przemysław Maj Uniwersytet Rzeszowski 